ESJ Social Sciences

\title{
Sociocultural Variables Influencing Female Pupils' School Dropout in the Asante Akim South Municipality of Ghana
}

\author{
Dr. Felix Senyametor \\ Department of Education and Psychology \\ University of Cape Coast, Ghana \\ Anane Agyei \\ Konongo Municipal Assembly 1 Junior High School \\ Ghana Education Service \\ Vincent Mensah Minadzi \\ College of Distance Education \\ University of Cape Coast, Ghana \\ Tahir Ahmed Andzie \\ Department of Business and Social Science Education \\ University of Cape Coast, Ghana
}

Doi:10.19044/esj.2021.v17n27p76

Submitted: 18 June 2021

Accepted: 24 July 2021

Published: 31 August 2021
Copyright 2021 Author(s)

Under Creative Commons BY-NC-ND

4.0 OPEN ACCESS

Cite As:

Senyametor F., Agyei A., Minadzi V.M. \& Andzie T.A. (2021). Sociocultural Variables Influencing Female Pupils' School Dropout in the Asante Akim South Municipality of Ghana. European Scientific Journal, ESJ, 17 (27), 76. https://doi.org/10.19044/esj.2021.v17n27p76

\section{Abstract}

Educating the girl-child has witnessed an elevated influence of women in education, politics, health, industry and sports among others. Advancing girls' education is probably the most cost-effective measure for an evolving country like Ghana and other nations to enrich womanhood. Sadly, the girls' education in Ghana appears to be on a downward trend due to their high school dropout rate. This study therefore investigated sociocultural factors influencing female school dropout -in the Asante Akim South Municipality of the Ashanti Region of Ghana. The descriptive design was employed for the study. A sample of 96, made up of 40 teachers and 56 female school dropouts was purposely selected out of a population of 3,543 from 10 public Junior High Schools. The questionnaire and structured interview were used for data collection. The results showed that some teachers' negative attitudes, persistent teacher and peer sexual harassment of female students, teenage 
pregnancy and some cultural practices among others were causes of female school dropout. It was recommended that regular workshops be organized by the Ghana Education Service for Junior High School (JHS) teachers on how to professionally handle the girl-child in schools in the Asante Akim South Municipality to enable the girls stay in school thereby reducing their dropout.

Keywords: Female, sociocultural, dropouts, girl-child, pupils, teachers

\section{Introduction}

Education is believed and accepted as a key factor to success. It is therefore not out of place that the 1992 constitution of Ghana places education under fundamental human rights (article 25 of chapter 5) and also recognized by the directive principles of state policy (article 38 of Chapter 6). Article 38 stipulates among others that, the state shall provide educational facilities at all levels and in all the regions of Ghana, and shall, to the greatest extent feasible, make those facilities available to all citizens. Consequently, Ghana in 1995, introduced Free Compulsory Universal Basic Education (FCUBE), School Feeding in 2002, and other interventions such as free textbooks, free exercise books and free school uniforms to ensure that all children of school going age in Ghana enjoy their constitutional right to education (Senyametor, Gyimah \& Minadzi, 2018). It is therefore, of grave concern why the issue of school dropout among pupils continues to be on the ascendancy in Ghana especially that of the female child.

The cultural-centeredness of education continuously dictates how much attention should be given to the female in her education and to what level she could reach. Priority is granted to the male child at the expense of the female child when it comes to matters relating to education (Bonneau, 2005). Education is considered as an investment in Africa but becomes liability when dropouts are recorded (Abu, 2015). Comparatively, boys at the ages of 16 and 17 are retained in school more than girls.

Many young girls enroll in schools but fail to be regular and progress to dropout (Sabate, Acheampong, Wesbrook\& Hunt, 2010).

The dropout rate is quite alarming worldwide especially in Africa (Nkwanazi \& Wet, 2014; Imoro, 2009). In the same vein, the UNESCO's (2010) reports on the state of the world's children, recorded about 1300000 children in the developing world who are denied their right to education through drop out. The United Nations Sustainable Development Goals (SDGs) which focuses on inclusive education has female education as its core epicenter. Specifically, Goal 4 on quality education and Goal 5 on gender equality are pivoted on female progress in our society (United Nations, 2014). Internationally, a meta-analysis report by Stark and McFarland (2015) indicated that between 2009 and 2012, 2.6 percent females had dropped out of 
school. Additionally, the Government of Ghana release on this trend in 2003 revealed that dropout rates skyrocketed in Ghana to about 20 percent for boys and 30 percent for girls at the Junior High School (JHS) level (Ampiah \& Adu-Yeboah, 2009) Retention from primary 6 to the end of JHS year 2 appears to stabilize and drops significantly for girls from Junior High School year 2 to Junior High School year 3 mainly as they approach the Basic Education Certification Examination (BECE) at the end of Junior High School year 3 (Government of Ghana (GoG), 2003).

New evidence emerging from the Consortium for Research on Educational Access, Transitions and Equity (CREATE) studies in Ghana pointed to other contributory factors to the female school dropout phenomenon such as; teacher unavailability, unsympathetic teacher attitudes to children who attend school irregularly due to poverty, school level practices such as corporal punishment and over age attendance (Ampiah \& Adu-Yeboah, 2009; Ananga, 2010). School safety and teenage pregnancy are factors that could not be ruled out of the equation on high risk of female school dropout (Tembon \& Fort, (2008). Notwithstanding empirical reports on the issue coupled with governmental intervention programmes geared towards promoting education for all children in Ghana, the issue of school dropout among female pupils continues to rise in many parts of Ghana. Asante Akim South Municipality in the Ashanti region of Ghana is no exception. The Ghana Statistical Service (GSS) and Ghana Health Service (GHS) reported that the 2010 Population and Housing Censusin the Asante Akim South Municipality recorded higher numbers of girls $(22.2 \%)$ than boys $(13.0 \%)$ who were out of school. The percentage of boys $(44.8 \%)$ currently in school is higher than that of the girls $(38.6 \%)$.

The municipality under study has a JHS pupils' population of 4210 (GES, Asante Akim South District education Office (2020). The researchers for the past four years have observed that the school dropout phenomenon of pupils particularly, the girls in the municipality was on the ascendancy and needs to be given a research attention. 


\section{The Concept School Dropout}

School dropout is seen when pupils who have permanently enrolled in schools suddenly stop attending school (Kaufman, Jiny, Steve \& Christopher, 1999). Wahba (2013) also defines school dropout as students who discontinue their programme of study or leave school before they finish their studies. According to Subrahmanyam (2016) children who access education at primary level have increased in developing countries and tremendous efforts have been put in place to ensure their retention in school. The issue of dropout however, cuts across both gender but there is a marked difference between dropout rates for males and females in Africa (Lambert, Parrino \& Barreras, 2012). For instance, the Organization for Economic Cooperation and Development (OECD) in its Educational Indicators on Malawi, points to primary school dropout rate of 65 percent in 2007 (UNICEF, 2015). Similarly, Sabates et al (2010) in Madagascar, 14 percent of 16 and 17 year olds did not have access to school but 30 percent of those who had enrolled in school dropped out.

The report continued that although school dropout persists in several countries, marginal efforts indicate an improvement in the rates. For instance, school retention improved in Grade 6, the final year of primary education, from 79.9 percent in 1998 to 85.8 percent in 2008 for Ghana. In all these, greater efforts demonstrated by these countries and other issues related to dropout continue to be a major concern for some on their national agenda. Incidence of school dropout is on the rise in developing countries and particularly in Africa. As reported by the World Bank (2015), about 58 million children are out of school and half of this number is found in African countries. The long term investment in education has become a short term investment with no returns as a result of school dropout at the basic school (Imoro, 2009). Countries in Sub-Saharan Africa are experiencing progress in pupils' retention but majority of them leave school not able to neither read nor write (UNESCO, 2013). Dropout has become a norm in most African countries. Across the sub-region over 10 million school children dropped out (Ghana News Agency, 2013). Dropout rates are even worse in Chad with 72 percent, Uganda 68 percent and Angola 68percent where more than two out of three youngsters, particularly girls dropout of school before reaching the final year (UNICEF, 2015). According to UNESCO (2012) dropout rate is higher for girls in 49 countries compared to boys across the world. Girls overall, attained less education and tend to drop out of school earlier than boys. Indeed, there are about 72 million pupils of school going age who are not accessing education and millions are dropping out without fundamental skills (Education for All, 2010).

According to the Ghana Education Service (GES, 2020) there is a consistent reduction in female enrolment from one ladder in education to another in Ghana. The typical rates for female enrolment stood at 50.1 percent 
at pre-school, 47.2 percent at primary school, 41.2 percent at the Junior High School (JHS) and 37.5 at the Senior High School (SHS) levels.

Kitcher (2000) is of the view that if all girls are sent to school and are encouraged to stay in school, then Ghana will see a strong and formidable female population work force. She further believes that even though Ghana has made a significant progress in the development of education since independence, the level of population of females in school still lagged behind that of their male counterparts.

\section{Theoretical Framework Self-efficacy Theory}

Self-efficacy is an inherent ability for one to pick a task and finish it. Self-efficacy theory tells us that people's belief in their capacities drive them to tackle only tasks they feel will be able to finish successfully and those that they believe they cannot successfully execute will demotivate them. When people are convinced that a task can be easily performed, individuals will be motivated to take up the task (Bandura, 1997).

Mastery experience occurs when people are successful at doing something. According to Bandura (1997), mastery experiences are the most effective way to boost self-efficacy because people are more likely to believe they can do something new if it is similar to something they have already done successfully. For instance, if girls found a direct link to what they do at home and what is taught in school, their accumulated experience would boost their stay in school. They are more likely to develop the confidence to stay in school for all periods required.

Another factor influencing perception of self-efficacy is vicarious experience. This is when a person watches or observes the success and failures of others. Watching one's peer to successfully accomplish a task increases selfefficacy. Conversely, the opposite outcome threatens self-efficacy. When girls observe that their role models such as parents, friends and elder siblings had suffered dropout there is a greater propensity that they might also dropout from school or feel inadequate to outperform their models.

Bandura (1997) further identified verbal persuasion as one factor that influences self-efficacy. When people are persuaded verbally that they can achieve or master a task, they are more likely to do the task. Having others' verbal support of attainment or mastery of a task goes a long way in supporting a person's belief in him or herself. So when girls are motivated by significant others that schooling provides a better prospect or advantage for a prosperous future, they are likely to develop a strong self-confidence towards their study and stay in school. Conversely, when they are frightened by the utterances of significant others they are likely not to take schooling seriously and possibly drop out. 


\section{Maslow's Hierarchy of Needs Theory}

Motivation of people is driven by five hierarchies of needs, according to Maslow (as cited in McLeod, 2018). Maslow's needs hierarchy includes physiological, safety, love, esteem and self-actualization needs. According to Maslow, needs of people are satisfied in sequence as other needs become prevalent when the previous one is achieved (Kreitner, 2009).Maslow however, made it clear that the hierarchy is not necessarily a fixed order. That is there will be a number of exceptions to the order. People therefore try to satisfy their basic needs that are important for their survival and development. At the bottom are physiological needs, which are, in essence, fundamental needs for human survival. These include the need for sensory pleasures, food, air, shelter, water, sleep and sex. Fulfillment of these lowest-level needs enables the individual to survive and nothing else is important when these bodily needs have not been satisfied. They are seen as fundamental biological drives (Kaur, 2013). Practically, it is an undeniable fact that when school pupils, especially girls go to school with empty stomachs, lack of their physiological needs in the form of food cause them to be demotivated and stay away from school. Other physiological needs for girls to stay in school include school uniform, sandals, sanitary pad and others. Also, when the basic needs of the girls in their homes are not adequately provided or denied by parents, education becomes burdensome for such children.

Secondly, safety needs are related to enemies and threats. It points to safety and security, freedom from pain and protection from danger. They relate to the environment at home and school (MacLeod, 2018). Some of the safety and security threats faced by girls in the school environment include sexual harassment from their male pupils and teachers, corporal punishment, intimidation, ridicule, discrimination among others. When safety and security for girls particularly are not guaranteed in the school environment, the expensive cost of drop out is paid. It is therefore expedient for school authorities to provide, congenial environment for the girls to feel at ease to contribute in class and share opinions without fear of ridicule and mockery. These should be done in the atmosphere of love. Love and social needs represent the need to be affiliated, and accepted by other people (Kaur, 2013). This category is a powerful motivator of human behaviour. These include affection, sense of belonging, social activities and friendships (Mullins, 2005). The first place to exhibit this is the home environment. How much love parents demonstrate to the girl-child would be a great catalyst to a successful school journey. Support in homework, attendance to Parent Teacher Association meetings (PTA), provision of school uniform and others would point to love from parents to the child.

Similarly, a parent's recognition of a child's accomplishment is important in satisfying the child's self-esteem (Kaur, 2013). When parents, 
teachers and others value the girl-child under their care, the problem of school dropout will be minimized. This implies taking advantage of every opportunity to reinforce positive behaviours they register with respect to schooling.

Self-actualization reflects the need to become everything that one is capable of becoming (Maslow, 1943). This is the development and realization of one's fullest potential (Kaur, 2013). A self-actualized girl in education will therefore become a valuable asset to the family, the nation and the world at large. Maslow indicates that few people will ever fully reach this level. The need for parents to help their wards reach this level in future cannot be overemphasized.

\section{The Female Pupil and School Dropout}

Girls in many societies face a number of sociocultural inequalities which affect their development and place them in a disadvantaged position (Kitcher, 2000). Globally, females from low-income level families and deprived regions are always disadvantaged in educational achievement (Subrahmanyam, 2016). Gender roles perception has placed girls in unfavourable situations with regards to rights, privileges, responsibilities, treatment and access to school. Misconception about female roles in the society in the developing countries contributes to low levels of females in schools. Some factors accounting for low enrolment directly corresponds with known causes for school dropout. The issue of girls coming from low-level income families, walking to school, unwanted pregnancy and abuse militate against progressive education of girls. These issues can be categorized into socio-economic factors, school level factors, household factors, cultural and religious factors among others (Sabates, et al, 2010).

\section{Social School-Based Factors that Influence Female School Dropout}

Many female pupils are discouraged owing to walking to school covering long distances on empty stomachs. Parents are upset by their girls covering long distances to school with associated sexual harassments (Nekatibeb, 2002). Vulnerability of the young girl to sexual harassment necessitates school dropout (Nekatibeb, 2002). Ainsworth (2005) posited that means of transport to school serve as motivation for girls, and particularly when adults send them to school. Research has shown that when pupils continue to be absent from school, it has a serious impact on dropping out (Shahidul\&Karim, 2015). Manacorda (2012) also revealed that girls suffer the consequences of absenteeism, repetition and dropout. Female pupils' absenteeism and dropout is also related to teenage pregnancy, excessive household chores, and menstrual cycle complications (UNICEF, 2015). 
Female teachers impact a greater amount of influence on girls' retention in school and educational achievement (Shahidul \& Karim (2015). According to Solotarroff (2007) Afghanistan, Pakistan and Ghana have a limited number of role models for girls which hinder their active engagement in school activities. Female teachers have a positive influence on academic performance of female pupils therefore, their absence in some schools are linked to female pupils' dropout from school (Carell, Marinne, Page \& James, 2010).

\section{Inadequate Sanitary Facilities and Teacher Attitudes}

The inadequate sanitary facilities (Toilets and urinals) and lack of privacy for girls have been reported to be among the major contributory factors of their school dropout (Birdsall, Levine \& Ibrahim, 2005; Gran, 2013). A follow up study confirmed that, the adolescent girls are very shy especially of the opposite sex. Therefore, when girls and boys use the same sanitary facilities, female students tend to absent themselves from school during menstrual periods and gradually lost interest in schooling (Kristof\&WeDun, 2009).UNICEF (2006) similarly found that shortage of proper washrooms in schools across Africa contribute to decreasing enrollment and attrition among girls in schools.

Research has revealed that teacher attitudes such, sexual harassment, use of unkind words and poor relationship with the female student are among the chief culprits of female school dropout (Chugh, 2011; FAWE, 2001).

\section{Pupil Related Causes \\ Poor Academic Performance and Indiscipline}

UNESCO (1997) found that academic failure was one of reasons why some girls dropout of school. Adolescence is a period of life during which individuals develop their personality and refine their interests (Thiruane, 2016). At this stage, most adolescents especially the girls are susceptible to negative influences from peers and models around them. Critical characteristic of this stage is the strong desire to be independent of adults and parental controls which often result in clashes between them, parents and teachers. This culminates in loss of interest in school and eventual dropout from school when not handled appropriately (Thiruane, 2016). This is due to the fact that most adolescents including girls want to be left alone to explore the world, but there are school rules to be adhered to and breaking these rules lead to conflict and indiscipline, causing their suspension from school. Schools' inability to have qualified staff to handle pupils carefully during this stage makes them feel neglected and more often than not abscond from school (Fernel, 2010). 


\section{Family and Cultural Variable}

\section{Early Marriage and Cultural Practices}

Holcamp (2009) found that educating girls after they have given birth to a child or two becomes very difficult and sometimes impossible. In Africa, girls are deemed marriageable on reaching puberty and in some cultures they are betrothed or given in marriage. Thus those of them in school are forced to stop school to take up their marital responsibilities. This has been found to be one of the major courses of girls dropping out of school in Ghana and Afghanistan (Masonry (2007). In Ghana, Trokosi is one of the cultural practices whereby young girls are sent to serve in shrines as payment for sins committed by their parents or relatives against the traditional gods they worship. Such girls are deprived of continual education (Frimpong, Brako, Dadson, \& Obeng, 2008). In the case of Bangladesh, Shahidul (2012) revealed that girls from poor homes dropout at the secondary school level and those who are able to attain higher education attract extremely high bride wealth in marriage.

Traditional beliefs hinder the progress of girls' education in many developing countries. Such traditional beliefs favour boys more than girls in education (Chege \& Sifuna 2006). Mothers in Africa play efficient roles in training the girls to master house chores (Atayi (2008). Many girls are prepared toward marriage and thus are educated in Ghana and Africa along those lines (Falkingham \& Baschieri, 2006). In a similar vein, parents and guardians in rural areas have strict adherence to traditions compared to their urban counterparts and do not allow girls to attend school (UNESCO, 2010).

\section{Teenage Pregnancy}

Boyle, Brock, Mace and Sibbons (2002) investigated and reported on early pregnancy of girls as a major cause of school dropout for girls. Dune and Leach (2005) also confirmed that higher dropout rate among girls is as a result of teenage pregnancy.

According to Grant and Hallam (2006), going back to school after pregnancy is predicated on availability of caregivers and the willingness of the mother to relinquish childcare responsibilities to other persons. This thrives on the fact that in some countries including Ghana, girls are allowed to come back to school after delivery. But the re-entry rate is not encouraging due to factors such as shyness, fear of teasing and mockery from peers (Dune \& Leach, 2005).

\section{Statement of the Problem}

As part of the 1992 Constitution of Ghana, female education has been given prior attention in order to curtail their dropout from school (International Finance Corporation, 2007). A number of females who have access to 
education dropout of school at the basic level, due to one reason or the other in Ghana (Senyametor, Gyimah \& Minadzi,2018). Many female pupils in the Asante Akim South municipality are no exception in this respect as they lose the precious opportunity of progressive schooling. Within the past four years only 35 percent girls at the JHS level in the municipality were able to complete school and write the Basic Education Certificate Examination (BECE) (Asante Akim South District Education Office, 2020).

Several research works have been conducted on the causes and impacts of pupils' absenteeism in some selected communities in Ghana and Ashanti Region (Senyametor, Nkrumah \& Donkor, 2020; Frimpong, Brako, Dadson, \& Obeng, 2008; Boyle, Brock, Mace \& Sibbons 2002) which mostly focused on both sexes and males, but fail to specially address issues militating against the girl-child education and dropout from school. It appears that no research has been done on the causes of JHS female school dropouts in the Asanti Akim South Municipality. This study, therefore, seeks to fill this gap.

\section{Objectives of the Study}

The objective of this study was to investigate school dropout among Junior High School (JHS) female pupils in the AsanteAkimSouth Municipality of the Ashanti Region. Specifically, the study, sought to:

1. Identify social school-based variables influencing female school dropout at Junior High Schools in the Asante Akim South Municipality

2. Determine pupil related causes of female school dropout at Junior High Schools in the Asante Akim South Municipality.

3. Ascertain family and cultural variables that cause female school dropout at Junior High Schools in the Asante Akim South Municipality.

\section{Research Questions}

1. What are the social school-based variables influencing female school dropout at the Junior High Schools in the Asante Akim South Municipality?

2. What are the pupil related causes of female school dropout at the Junior High Schools in the Asante Akim South Municipality?

3. What are the family and cultural variables influencing female school dropout at the Junior High Schools in the Asante Akim South Municipality? 


\section{Methods}

\section{Research Design}

The descriptive research design was adopted for the study. The descriptive design was employed to enable us to describe, analyze, interpret and report the feelings and opinions of respondents related to the phenomenon understudy.

\section{Population and Sample}

The target population of study included head teachers and teachers, pupils in all the 55 Junior High Schools in the municipality, numbering 3,543. A sample of 96 comprising 40 teachers and 56 female school dropouts was purposely selected from 10 Junior High schools. The dropouts were identified with the aid of the school attendance registers. Schools in which the girls were found too were selected purposely. The choice of purposive sampling was employed in order to sample only the affected respondents (Girls dropped out of school) who were knowledgeable about the phenomenon under investigation to give information relevant to the study.

\section{Instruments}

\section{Structured Interview and Questionnaire}

Structured interview was used to collect data from female dropouts. This provided some interactive platform for the researchers and the respondents as most of them were deficient in the English Language. Closedended questionnaire was used to collect data from the head teachers and teachers.

\section{Data Collection and Analysis}

Data from female dropouts were obtained with the structured interview at their homes. Some of the questions were translated in Asante-Twi (a local language spoken in the area). Prior to data collection the school attendance registers were used to identify the female school dropouts. Data collected were analyzed using frequency and percentage counts. This was done with the aid of statistical package for social sciences (SPSS) software version 20.

\section{Results and Discussion of Findings}

This section presents the results pertaining to the research questions. The items for the head teachers and teachers were measured on a discrete fivepoint scale of 1-5 ranging from Strongly Disagree (SD), Disagree (D), Undecided (U), Agree(A) to Strongly Agree (SA). The responses agree and strongly agree were pulled together as agreed; strongly disagree and disagree were also pulled together as disagreed while undecided stood separately. The items for the school dropouts were measured on a discrete three-point scale of 
one to three ranging from 'Neutral', 'No' and 'Yes'. The responses are presented in Table 1.

\section{Research Question One: What are the social school-based variables influencing female school dropout in the Asante Akim South Municipality?}

Six items were outlined and used to answer question one. The results are presented in Table 1 and 2.

Table 1: Teachers Response on Social School-Based variables Influencing Female School Dropout in the Asante Akim South Municipality

\begin{tabular}{|c|c|c|c|c|c|}
\hline Statements & $\begin{array}{l}\text { SD } \\
\text { №(\%) }\end{array}$ & $\begin{array}{l}\mathrm{D} \\
\text { №(\%) }\end{array}$ & $\begin{array}{l}\text { U } \\
\text { №(\%) }\end{array}$ & $\begin{array}{l}\text { A } \\
\text { №(\%) }\end{array}$ & $\begin{array}{l}\text { SA } \\
\text { №(\%) }\end{array}$ \\
\hline $\begin{array}{l}\text { Negative attitude of teachers in considering girl- } \\
\text { child education less important than that of boys } \\
\text { affects girls' retention in school. }\end{array}$ & $19(47.5)$ & $13(32.5)$ & 0 & $3(7.5)$ & $5(12.5)$ \\
\hline $\begin{array}{l}\text { Some teachers discourage and downgrade the girl- } \\
\text { child in the teaching and learning process. }\end{array}$ & $6(15.0)$ & $3(7.5)$ & $3(7.5)$ & $17(42.5)$ & $11(27.5)$ \\
\hline $\begin{array}{l}\text { I experience insecurity, fatigue and threats due to } \\
\text { long distance from home to school }\end{array}$ & $10(25.0)$ & $7(17.5)$ & $2(5)$ & $11(27.5)$ & $10(25)$ \\
\hline $\begin{array}{l}\text { School management often disregards and fails to } \\
\text { address abuses and intimidation reported by girls. }\end{array}$ & $9(22.5)$ & $3(7.5)$ & 0 & $10(25.0)$ & $18(45)$ \\
\hline $\begin{array}{l}\text { Some girls are harassed due to inappropriate } \\
\text { sanitation facilities for their privacy at school. }\end{array}$ & $5(12.5)$ & $7(17.5)$ & 0 & $10(25.0)$ & $18(45)$ \\
\hline $\begin{array}{l}\text { Most girls dropout from school due to pregnancy } \\
\text { and frequent sexual harassment by some teachers } \\
\text { and peers. }\end{array}$ & $9(22.5)$ & $5(12.5)$ & 0 & $3(7.5)$ & $23(57.5)$ \\
\hline
\end{tabular}

Source: Field Survey, $2020 \quad \mathrm{~N}=4$

The result from Table 1, on the statement of some teachers considering the girl-child education less important than that of boys thereby affecting girls' retention in school, indicated that, majority (32) of teachers representing 80 percent disagreed. However, on the statement of discouragement and downgrading of girls in the teaching-learning process by some teachers, the majority of teachers (28) representing 70 percent agreed. This finding corroborates that of FAWE (2001) who found that some teachers were not measured in the use of their language toward girls in the classroom particularly those that appear to be dull and irregular at school. Also, on the issue of girls being harassed due to inappropriate sanitation facilities for their privacy, majority (28) representing 70 percent of teachers agreed to the statement. This affirms the revelation of Birdsall et al (2005) that girls' privacy issue in schools is one of the foremost factors which compels them to drop out from school. The finding is also in congruence with Maslow's need theory (as cited in McLeod, 2018) about the need to provide physiological needs to people as a prerequisite for motivation and growth toward self-actualization. 
Table 2: Female Dropouts Response on Social School-Based Variables influencing their dropout of School in the Asante Akim South Municipality

\begin{tabular}{|c|c|c|c|}
\hline Statement & $\begin{array}{l}\text { Students } \\
\text { Neutral } \\
№(\%)\end{array}$ & $\begin{array}{l}\text { № } \\
\text { №(\%) }\end{array}$ & $\begin{array}{l}\text { Yes } \\
\text { №(\%) }\end{array}$ \\
\hline $\begin{array}{l}\text { Negative attitude of teachers in considering girl-child } \\
\text { education less important than that of boys affects } \\
\text { girls' retention in school }\end{array}$ & 0 & $7(12.5)$ & 49 (87.5) \\
\hline $\begin{array}{l}\text { Some teachers Discourage and downgrade the girl- } \\
\text { child in the teaching and learning process. }\end{array}$ & 0 & $10(17.9)$ & $46(82.1)$ \\
\hline $\begin{array}{l}\text { I experience insecurity, fatigue and threats due to the } \\
\text { long distance from home to school. }\end{array}$ & $2(3.5)$ & $40(71.4)$ & $14(25)$ \\
\hline $\begin{array}{l}\text { School management disregards and fails to address } \\
\text { abuses and intimidation reported by the girl-child. }\end{array}$ & 0 & $2(3.6)$ & $54(96.4)$ \\
\hline $\begin{array}{l}\text { Some girls are harassed due to inappropriate sanitation } \\
\text { facilities for their privacy at school. }\end{array}$ & 0 & $1(1.8)$ & $55(98.2)$ \\
\hline $\begin{array}{l}\text { Most girls dropout from school due to pregnancy and } \\
\text { frequent sexual harassment by some teachers and } \\
\text { peers. }\end{array}$ & 0 & $3(5.4)$ & $53(94.6)$ \\
\hline
\end{tabular}

Source: Field Survey, $2020 \mathrm{~N}=56$

Table 2, presents results from female dropouts based on how the negative attitude of their teachers in considering girls' education less important than that of the boys affects their retention in school. Majority (49) representing 87.5 percent of female dropouts responded 'Yes'. This finding contradicts sharply with that of their teachers on the same statement. This contradictory revelation speaks to an intrinsic nature of human beings to save themselves from embarrassing situations thereby enhancing their self-esteem (Maslow (as cited in McLeod, 2018). One cannot, however, completely discount the claim of the students against their teachers because they are the receiving end of most of the things happening in the schools.

Also, on the statement of girls harassed due to inappropriate sanitation facilities for their privacy, the majority (55) representing 98.2 percent of the dropouts responded 'Yes' to the statement. In line with this finding, Tembon (2008) confirmed that school safety factors could explain the higher risk of school dropout for girls. So also was it found that inadequate sanitation facilities in schools such as lack of private and separate latrines for girls' aggravate school dropout (GCE, 2012).

Regarding the issue of most girls dropping out from school due to pregnancy and frequent sexual harassment by some teachers and peers, causing school dropout, majority (53) representing (94.6)percent of female dropouts agreed to the statement. Majority of teachers' (26 representing $65 \%$ ) response on the same issue confirmed that of their female school dropouts. These finding is in line with what research has revealed on teacher attitudes such, sexual harassment, use of unkind words and poor relationship with the 
female students being among the chief culprits of female school dropout (Nekatibeb, 2002; Chugh, 2011\&FAWE, 2001).This calls for provision of sexual safety and security for the girls in order to forestall their dropout from school.

\section{Research Question Two}

What are the pupil-related factors influencing female school dropout at the Junior High Schools in the Asante Akim South Municipality?

Item seven to twelve of the questionnaire answered this research question. Responses to various questions by teachers and dropouts are presented in Table 3 and 4.

Table 3: Teachers Response on Pupil-related Factors Influencing Female School Drop out in the Asante Akim South Municipality

\begin{tabular}{lccccc}
\hline Statement & SD & D & U & A & SA \\
\cline { 2 - 6 } & №(\%) & №(\%) & №(\%) & №(\%) & №(\%) \\
\hline $\begin{array}{l}\text { Tiredness from assigned household } \\
\text { chores before going to school. }\end{array}$ & $5(12.5)$ & $7(17.5)$ & $3(7.5)$ & $10(25.0)$ & $15(37.5)$ \\
$\begin{array}{l}\text { Disregard and lack of motivation in } \\
\text { gaining education. }\end{array}$ & $6(15.0)$ & $3(7.5)$ & $6(15.0)$ & $16(40.0)$ & $9(22.5)$ \\
$\begin{array}{l}\text { Sidelining and humiliation due to poor } \\
\text { academic performance }\end{array}$ & $7(17.5)$ & $5(12.5)$ & 0 & $8(20.0)$ & $20(50.0)$ \\
$\begin{array}{l}\text { Negative influence relating to earning } \\
\text { income as peers who are drop outs. }\end{array}$ & $15(37.5)$ & $11(27.5)$ & 0 & $5(12.5)$ & $9(22.5)$ \\
$\begin{array}{l}\text { Once a teenage girl is pregnant } \\
\text { dropping out from school is high. }\end{array}$ & 0 & 0 & 0 & $11(27.5)$ & $29(72.5)$ \\
$\begin{array}{l}\text { Personal indiscipline with regular } \\
\text { breaking of school rules and regulation } \\
\text { and clashes with school authorities. }\end{array}$ & $9(22.5)$ & $6(15.0)$ & $4(10.0)$ & $8(20.0)$ & $13(32.5)$ \\
\hline
\end{tabular}

Results from Table 3 on responses from teachers on the issue pertaining to, tiredness from assigned home chores before going to school leading to female drop out showed that majority (25) of teachers representing 62.5 percent agree to the statement. This finding is in congruent with Atayi (2008) who found that in Africa, parents are more concerned about assigning specific household chores for girls to complete daily, especially in the morning and evening.

Furthermore, as seen in the statement on the issue of sidelining and humiliating girls due to poor academic performance, the majority (28) representing 70 percent of teachers agreed to the statement. This finding calls for attitudinal change on the part of the teachers involved and conscious work at creating loving atmosphere for the girls and enhancing their self-efficacy, which is mediated by training and skill acquisition (Bandura, 1997; MacLeod, 2018). 
Table 4: Female Dropouts' Response on their related Factors Influencing their Drop out of School in the Asante Akim South Municipality

\begin{tabular}{|c|c|c|c|}
\hline \multirow{3}{*}{ Statement } & \multicolumn{3}{|l|}{ Students } \\
\hline & Neutral & No & Yes \\
\hline & №(\%) & №(\%) & №(\%) \\
\hline Tiredness from assigned home chores before going to school. & $5(9.0)$ & $11(19.6)$ & $40(71.4)$ \\
\hline Disregard and lack of motivation in gaining education. & 0 & $33(59.0)$ & $23(41.0)$ \\
\hline Sidelining and humiliation due to poor academic performance & $3(5.4)$ & $12(21.4)$ & $41(73.2)$ \\
\hline Once a teenage girl is pregnant dropping out from school is high. & 0 & $11(19.6)$ & $45(80.4)$ \\
\hline $\begin{array}{l}\text { Personal indiscipline with regular breaking of school rules and } \\
\text { regulation and clashes with school authorities. }\end{array}$ & $5(9.0)$ & $12(21.0)$ & $39(70.0)$ \\
\hline
\end{tabular}

\section{Source: Field Survey, $2020 \quad \mathrm{~N}=56$}

Results From Table 4 based on responses from students dropouts to the statement on tiredness from assigned home chores before going to school leading to their drop out, majority (40) representing (71.4) responded 'Yes' to the statement, while 11(19.6) of them disagreed. This finding confirms that of their teachers on the same statement. There is therefore, the need for parents to reduce household chores they assign to their female children to do in the morning before going to school.

Also, on the issue of once a teenage girl becomes pregnant, dropping out from school is high, the majority (45) representing80.4 percent of the female dropouts responded 'Yes' to the statement. This finding confirms that of Dune and Leach (2005;Boyle et al, 2002) who found that higher dropout rate among girls is as a result of teenage pregnancy.

\section{Research Question Three \\ What are the family and cultural variables influencing female school dropout at the Junior High School in the Asante Akim South Municipality?}

Six items were used to answer this research question. Responses to the statements by teachers and female school dropouts are presented in Table 5 and 6. 
Table 5: Teachers' Response on Family and Cultural Variables Influencing Female School Drop out in the Asante Akim South Municipality.

\begin{tabular}{|c|c|c|c|c|c|}
\hline \multirow[t]{2}{*}{ Statement } & SD & $\mathrm{D}$ & $\mathrm{U}$ & A & SA \\
\hline & №( $(\%)$ & №(\%) & №(\%) & №( $(\%)$ & №(\%) \\
\hline $\begin{array}{l}\text { Most families and cultural traditions } \\
\text { favour male education than female } \\
\text { education. }\end{array}$ & $4(10.0)$ & $2(5.0)$ & 0 & $25(62.5)$ & $9(22.5)$ \\
\hline $\begin{array}{l}\text { Some parents consider spending money } \\
\text { on girl-child education a waste as the } \\
\text { girl-child will ultimately get married. } \\
\text { Girl-child deserting school to }\end{array}$ & $9(22.5)$ & $3(7.5)$ & 0 & $16(40.0)$ & $12(30.0)$ \\
\hline $\begin{array}{l}\text { supplement family earning due to poor } \\
\text { financial status of parents. }\end{array}$ & $7(17.5)$ & $11(27.5)$ & 0 & $9(22.5)$ & $13(32.5)$ \\
\hline $\begin{array}{l}\text { Low level of education of parents } \\
\text { contributes to female school dropout. }\end{array}$ & $11(27.5)$ & $5(12.5)$ & $3(7.5)$ & $14(35.0)$ & $7(17.5)$ \\
\hline $\begin{array}{l}\text { Some families which consider the girl- } \\
\text { child as an asset give the girl in early } \\
\text { marriage to earn dowry causes female } \\
\text { school dropout }\end{array}$ & $6(15.0)$ & $4(10.0)$ & 0 & $18(45.0)$ & $12(30.0)$ \\
\hline
\end{tabular}

Table 5, presents results based on responses from teachers' on the issue of families and cultural traditions favouring male education more than female education. Majority (34) representing 85 percent of them agreed to the statement. This finding is in tandem with Chege and Sifuna (2006) who revealed that many cultures in sub-Saharan Africa favour education for boys rather than girls.

Similarly, on the issue of how some parents consider spending money on girls' education as waste because the girls would ultimately get married and leave home, the majority (28) representing 70 percent of teachers agreed. This finding could not agree more with that of Holcamp (2009) who found that rural girls' dropout rate is on the ascendancy because some parents consider girls' schooling as waste because they would leave their parents to form their own families. This mentality of some parents in Ghana and Africa is born out of the tradition which requires male children to stay in their parents' homes, marry and bring their wives home to take care of them and their parents. Females on the other hand, are required to leave their parents' homes to stay with their husbands, take care of them and their in-laws. 
Table 6: Female Dropouts' Response on Family and Cultural Variables Influencing their Drop out of School in the Asante Akim Municipality

\begin{tabular}{lccc}
\hline Statement & $\begin{array}{l}\text { Students } \\
\text { Neutral } \\
\text { №(\%) }\end{array}$ & $\begin{array}{l}\text { No } \\
\text { №(\%) }\end{array}$ & $\begin{array}{l}\text { Yes } \\
\text { №(\%) }\end{array}$ \\
\hline $\begin{array}{l}\text { Most families and cultural traditions favour male education } \\
\text { more than female education. }\end{array}$ & 0 & $4(7.0)$ & $52(93.0)$ \\
$\begin{array}{l}\text { Some parents consider spending money on girl-child education } \\
\text { a waste as the girl-child will ultimately get married. }\end{array}$ & $3(5.4)$ & $10(17.8)$ & $43(76.8)$ \\
$\begin{array}{l}\text { Girl-child deserting school to supplement family earning due } \\
\text { to poor financial status of parents. }\end{array}$ & $6(10.7)$ & $11(19.6)$ & $39(69.7)$ \\
$\begin{array}{l}\text { Low level of education of parents contributes to female school } \\
\text { dropout. }\end{array}$ & $6(10.7)$ & $15(26.8)$ & $35(62.5)$ \\
$\begin{array}{l}\text { Cultural practices that encourage forced marriages and early } \\
\text { marriages hamper female education leading to female drop } \\
\text { out. }\end{array}$ & $2(3.6)$ & $44(78.6)$ & $10(17.8)$ \\
\hline \multicolumn{4}{c}{ Source: Field Survey, 2020 } \\
\hline
\end{tabular}

Results from Table 7 based on responses from Female school dropouts confirm that of their teachers' on Table 6, except their response on the statement regarding cultural practices that encourage forced marriages and early marriages hampering female education leading to their drop out. Majority (44) representing 78.6 percent disagreed while 10 representing 17.8 percent of the dropouts agreed to the statement. Their responses contradict that of their teachers. That notwithstanding, it is unarguable that the girls are often the ones at the receiving end of the early marriage cultural practice. Therefore, their disagreement to the statement means that forced early marriage cultural practice is not one of the causes of female school dropout in the Asante Akim South Municipality.

This finding contradicts that of Masonry (2007) and Frimpong, Brako, Dadson and Obeng (2008) who found that cultural practices like forced early marriage and Trokosi whereby young girls are sent to serve in shrines, and to marry the gods as payment for sins committed by their parents or relatives are among major courses of girls dropping out of school in Ghana and Afghanistan.

\section{Summary of Key Findings}

The following are the key findings of the study.

1. Seventy to 95 percent of respondents reported that inappropriate sanitary facilities and lack of privacy for girls was among school-based factors causing female school dropout in the Asante Akim South Municipality.

2. On the issue of sexual harassment by teachers and peers, as well as teenage pregnancy, 94 percent of the respondents revealed that it was 
among the chief factors causing female school drop out in the Asante Akim South Municipality.

3. Eighty five (85) percent of the respondents revealed that Cultural and parental child rearing practices prioritizing boys' education over girls' education was also responsible for female school drop out in the Asante Akim South Municipality.

4. The study further revealed that forced early marriage cultural practice is not responsible for female school dropout in the Asante Akim South Municipality.

\section{Conclusion and Recommendations}

The results from this study showed that teachers, pupils and the society' culture contributed to female school dropouts. It is evident that women's involvement and representation in social, economic, cultural and political advancement in Ghana is threatened due to the low number of literate females in the society. Existing literature on the phenomenon have shown that the issues militating against female school attendance and drop out cut across predominantly the African continent. It is about time more research works were conducted into the phenomenon on regional, national and continental bases in order to promote research based policies by the governments across the continent targeted at the teenage girls especially in the basic schools. Based on the findings of the study, the following recommendations are made:

Regular workshops should be organized by the Ghana Education Service for Junior High School (JHS) teachers on how to professionally handle the girl-child in schools in the Asante Akim South Municipality to enable the girls stay in school thereby reducing their dropout. Adequate facilities like toilets and urinals should also be provided and designed specifically to be female user friendly to ensure utmost privacy of the school girls.

Future research works are suggested to be conducted into the phenomenon on national and continental levels to enhance policy based interventions by governments and education managers.

Furthermore, teenage girls who have conceived whilst in school must be counselled immediately with the support of the appropriate authorities and encouraged to stay in school, the Guidance and Counselling Coordinators at the Junior High Schools and District Offices should be well resourced to be able to organize regular interactive sessions with female pupils on the importance of education, effects of promiscuous lifestyle and undisciplined behaviour. Also, the government of Ghana and district Assemblies should prioritize the eradication of cultural practices that hamper girl-child education through sensitization programmes, workshops and seminars with the active participation of all stakeholders in the education sector. Finally, teenage 
mothers must be supported by the Ministry of education and family members to return to school and complete.

\section{References:}

1. Abu, A. (2015). Effects of school drop-out in basic schools on the Nasuan community of the bunkpurugu-yuonyoo district of northern region. University of Development Studies. www.udsspace.uds.edu.gh

2. Ainsworth, M. (2005).Socioeconomic determinants of fertility in SubSaharan Africa: $\quad$ A Summary of the findings of a world bank research project. Washington Press.

3. Ampiah, G. J. \& Adu-Yeboah, C. (2009).Mapping the incidence of school dropout: a case study of communities in northern Ghana, comparative education. https://.org/10.1080/03050060902920625

4. Ananga, E. (2010). 'Understanding the push and pull factors in school dropout: A case study of southern ghana, CREATE monograph series (forthcoming) Brighton. The World Bank.

5. Asante Akim South District Education Office (2020). Basic school pupil population, 2019/2020. Juaso: Ghana.

6. Atayi, J.B. (2008). Disabling barriers to girls' primary education in Aura district (Uganda)-an intersectional analysis. Published Master of Arts thesis at the Institute of Social Studies, Uganda.

7. Bandura, A. (1977). Social learning theory. General Learning Press.

8. Bandura, A. (1997). Self-efficacy; the exercise of control. Freeman

9. Birdsall, N., Levine, R., \& Ibrahim, A. (Eds). (2005). Towards universal primary education: investments, incentives and institutions. Taylor and Francis.

10. Boyle. S., Brock, A., Mace, J. \&Sibbons, M. (2002). Reaching the poor: the cost of sending children to school. Synthesis report. DFID.

11. Bonneau, K. (2005). What is a dropout, Center for Child and family policy: North Carolina Education Research Data Center.

12. Carell, S. E., Marinne, E., Page \& James, E. (2010). Sex and science; how professor gender perpetuates the gap.

https://.org/10.1162/qjec.2010.125.3.1101

13. Chege, F., \&Sifuna, D. N. (2006).Girls and women's education in Kenya gender perspectives and trends. www.Library.unescoiiba.org/.../Girls\%20Education/.../Girls\%20and $\% 2$. 
14. Chugh, S. (2011). Dropout in secondary education. A study of children living in slums of Delhi. National University of Educational planning and Administration.

15. Dunne, M. \& Leach, F. (2005). Gendered school experiences: The impact on retention and achievement. The Quality Imperative

16. Education For All (2010). Global monitoring report. http://www.unesco.org.

17. Falkingham, J.\& Baschieri, A. (2006).Formalizing informal payments; the progress of health reform in Kyrgystan.Central Asian Survey.

https://www.tandfonline.com/doi/full/10.1080/02634930701210435

18. FAWE, (2001).Gender responsive school management systems. Nairobi: Forumfor African women educationists. http/www.ungei.org/files/FAWE_GRP_ENGLISH _VERSION.pdf

19. Fernel, M. (2010). Popular school at risk of closure, Thrive Educational Supplement 1(1), 26-27.

20. Frimpong, F. P., Brako, I., Dadson, I. Y., \&Obeng, I. J. (2008). SWL social studies for junior high schools; pupil's book 1. Sam-Woode Ltd.

21. GES, (2020).A national vision for girls' education in Ghana and a framework for action: Charting the way forward. Technical report.

22. Ghana News Agency (2013).Over half of the world's 58 million school drop-outs account.

https://www.preventionweb.net/organizations/5732

23. Government of Ghana.(2003). Ghana poverty reduction Strategy. https://www.imf.org/external/pubs/ft/scr/2006/cr06225.pdf

24. Graham, M. W. \&Messner, P. E. (1998). Principals and job satisfaction. International Journal of Education Management. 12 (5).196-204.

25. Grant, M. \& Hallman, K. (2006).Pregnancy related school dropout and prior school performance in South Africa. Policy Research Division Working Paper No 212. Population Council.

26. Holcamp, G. (2009).Researching the girls' dropout rate in Malawi. Why girls dropout of Primary school and what way this rate can be reduced. Journal of Education and Practice. 11(10), 1-9

27. Imoro, B. (2009). Dimension of Basic School Dropouts in Rural Ghana: Department of Planning-KNUST. Journal of Science and Technology, 29 (3) 72-85

28. International Finance Corporation (2007). Gender and Economic Growth Assessment for Ghana.

https://www.ifc.org/wps/wcm/connect/16959f24-f4ce-4fc1-9174-

37be68ea364c/Ghana\%2BGender\%2BAssessment.pdf?MOD 
$=$ AJPERES $\&$ CACHEID $=\mathrm{R}$ OOTWORKSPACE-16959f24-f4ce4fc1-9174-37be68ea364c-jqeKr61

29. Kaufman, P., Jiny. K., Steve K., \& Christopher D. C. (1999). Dropout rates in united states US department of education. National Center for Education Statistics. https://www.uregina.ca/library/assets/docs/pdf/finding_aids/89_44.pd $\mathrm{f}$

30. Kaur, A. (2013). Maslow's Need Hierarchy Theory: Applications and Criticisms. Global Journal of Management and Business Studies, 10 (3), 1061-1064.

31. Kitcher, M. (2000).Education-the best legacy for girls. Daily Graphic, March, 30

32. Kreitner, R. (2009). Management (11 ${ }^{\text {th }}$ ed.). South Western Cengage Learning.

33. Kristof, N. D. \& WeDunn, S. (2009). Half of the sky: Turning oppression into opportunity for women worldwide. Alfred Knopf Press

34. Lambert, M., Perrino, S. E., \& Barreras, M. E. (2012).Understanding the barriers to female education in Ghana.

https://www.semanticscholar.org/paper/Understanding-theBarriersto-Female-Education-inLambertPerrino/9c9f037f589b6c38f377fecd8ec794ebf0793e0e

35. Mansory, A. (2007). Drop out study in basic education level of schools in Afghanistan, Kabul: Swedish Committee for Afghanistan. https://www.nzdl.org/gsdlmod

36. Maslow, A. H. (1943). A theory of human motivation. Psychological Review, 50(4), 370- 96.

37. McLeod, S. A. (2018, May 21). Maslow's hierarchy of needs. https://www.simplypsychology.org/maslow.html

38. Mullins, L. J. (2005). Management and organizational behaviour ( $7^{\text {th }}$ ed.). Harlow: Prentice Hall Financial Times.

39. Nekatibeb, T. (2002).Low participation of female students in primary education. $\quad \mathrm{http}: / / \mathrm{www}$. create-rpc.org/pdf_documents/PTA55.pdf

40. Nkwanazi, S. \& Wet, D. N. (2014).School dropout among African adolescents in South Africa: Is there any gender differentials: Gender and Behaviour, (12), 5930-5952

41. Sabates, R., Akyeampong, K., Westbrook, J \& Hunt, F. (2010). School Dropout: Patterns, causes, changes and policies. https://www.researchgate.net/publication/336676395_School_Drop_ out_Patterns_Causes_Changes_and_Policies

42. Senyametor, F.,Gyimah,K.E., \&Minadzi,V. M. (2018).Factors Affecting Pupils' Absenteeism at Felicormfort Junior High 
School (JHS) in Cape Coast, Ghana. Journal of Education and Learning. 7(6), 2018

43. Senyametor, F., Nkrumah, K., \& Donkor, K. (2020). Impact of Positive Reinforcement on Pupils' Absenteeism: A Case Study at Felicomfort Junior High School (JHS), Amamoma in Cape Coast, Ghana. Journal of Education and Practice. 4(2) 53-69.

44. Shahidul, S. M. (2012). Marriage Market and an Effect on Girls' School Dropout in Bangladesh. .Journal of Alternative Perspective in the Social Sciences the Social Sciences, 2 (4), 552- 564.

45. Shahidul, S. M., \&Karim, Z. A. H. M., (2015). Factors contributing to school dropout among girls.

https://researchdirect.westernsydney.edu.au/islandora/object/uws $\% 3$

A38505/datastream/PDF/view

46. Solotarroff, J. (2007). Afghanistan mainstreaming implementation, Note Series, No.1: The World Bank in South Asia. http//siteresouircres.worldbank.org

47. Stark, P. \& McFarland, J. (2015).Trends in high school dropout and completion rates in the United States: 1972-2012. https://nces.ed.gov/pubs2015/2015015.pdf

48. Subrahmanyam, G. (2016). Gender perspective on causes and effects of school dropout. In Develop AB

49. Tembon, M., \& Fort, L. (Eds.). (2008). Girl's education in the 21 st century: Gender equality, empowerment and economic growth. The World Bank.

50. Thiruane, K. R. (2016). Investigating the causes of pupils dropout in public primary schools in Imenti North Sub County, Meru County, Kenya. Unpublished Masters' Thesis KCA University.

51. UNESCO (1997). World declaration on education for All. Adopted by the World Conference on Education for All.Jomtien, Thailand5-9 March.

https://www.humanium.org/en/world-declaration-on-education-forall/

52. UNESCO, (2010).EFA Global Monitoring Report 2010-Reaching the Marginalized. UNESCO Publishing.

53. UNESCO (2013), Education for rural development: a portfolio of studies; education and rural community. http://www.fao.org/3/ad423e/ad423e.pdf

54. UNICEF (2006). We can do a much better Job! The Malawian process to community based school sanitation. UNICEF: New York. http://www.washinschools.info/page/323.

55. UNICEF, (2015).Girls' education and gender equality. htttps://www.unicef.org/education/bege_70640.html. 
56. UNESCO (2012). Global Education Digest 2012. UIS Press

57. United Nations (2014).The millennium development goals report 2014 Dropout.

www.W0w0w00+nb.unevoc.unesco.org/go.php?q=TVETipedia+Glo ssary + A-Z\&term $=$ Dropout

58. World Bank (2015).Millennium Development Goals: Achieve universal primary education by 2015.

59. http://www.worldbank.org/mdgs/education.html 